\title{
New British Pliocene species of the Australian Recent genus Austroparadoxostoma Hartmann, 1979 (Ostracoda)
}

\author{
R. C. WHATLEY \& C. MAYBURY \\ Department of Geology, University College of Wales, Aberystwyth, U.K.
}

\begin{abstract}
Two new Pliocene species of the genus Austroparadoxostoma Hartmann, 1979; Austroparadoxostoma pliocenica and Austroparadoxostoma sp. are described from the Upper Pliocene deposits of St. Erth, Cornwall. This genus has hereto only been recorded from the Recent of the west coast of Australia.
\end{abstract}

\section{INTRODUCTION}

The Pliocene specimens described and illustrated herein were initially difficult to assign to any previously described paradoxostomatid genus. They appeared most closely to resemble the genus Austroparadoxostoma Hartmann, 1979 a Recent form from Goode Beach, (Frenchman Bay), near Albany on the west coast of Australia. Unfortunately, however, Hartmann did not figure an external view of the type species, $A$. ventromarginalis and his description of the species lacked reference to the hinge and inner lamella. These features could not be appreciated from his illustrations which were, in addition, based upon a single male specimen and one empty carapace. Electron micrographs of the Pliocene specimens were sent to Hartmann for comparison with the type material. Hartmann (lit. comm., 1981) confirmed that the Pliocene material could be firmly assigned to Austroparadoxostoma, but thought that the hinge structure of $A$. ventromarginalis differed from that of the Pliocene specimens. His photographs, he maintained, were too small to obtain detail of the hinge elements and suggested that the hinge structure may indeed not be uniform within the genus, as is the case of the closely related Paradoxostoma Fischer, 1855.

The occurrence, therefore, of further specimens of Hartmann's genus in the St. Erth Beds has permitted us to study the hinge and inner lamella and offer an emended carapace diagnosis for the genus.

The type material is housed in the Department of Palaeontology, British Museum (Natural History).

\section{SYSTEMATIC DESCRIPTIONS}

Class Ostracoda Latreille, 1806 Order Podocopida Müller, 1894

Suborder Podocopina Sars, 1866

Superfamily Cytheracea Baird, 1850

Family Paradoxostomatidae Brady \& Norman, 1889

Genus Austroparadoxostoma Hartmann, 1979

Type Species. Austroparadoxostoma ventromarginalis Hartmann, 1979.
Emended Diagnosis. A medium to large paradoxostomatid with a prominent keel-like, ventrolateral alar ridge and well developed caudal process. Surface smooth. Normal pore canals simple and open. Inner lamella wide at each end with a subtriangular vestibule developed anteriorly and a very narrow crescentic vestibule posteriorly. In the Pliocene species the hinge of the RV lacks an anterior terminal element but the median element comprises a wide, dorsally locellate groove, closed by a ventral ridge and a posterior terminal element of a socket and trilobate bar. In the LV the hinge is composed of 2 terminal sockets and a wide median bar. Both posterior terminal elements are bounded internally by an inverted " $L$ "-shaped elevation. Four subvertical, closely adjacent to contiguous or discrete and divided adductors and a fulcral point situated unusually close to an irregularly shaped frontal scar.

Remarks. Boldella Keij, 1957; Javanella Kingma, 1948; certain species of Paradoxostoma Fischer, 1855; Pellucistoma Coryell \& Fields, 1937 and Xiphichilus Brady, 1870 all resemble Austroparadoxostoma in their possession of a caudal process; but differ in all other morphological details of the valves (with the exception of the normal pore canals which are simple and open in all paradoxostomatids). Javanella, however, possesses a hinge which lacks both anterior and posterior terminal elements and comprises, in the RV, a narrow, finely locellate median groove with an anterior, elongate antislip tooth below this groove. Boldella, Microcythere Müller, 1894 and Pellucistoma also have a locellate groove as the median element of the RV hinge; but the hinges of these 4 genera bear only the similarity of their locellate grooves to the hinge structure of the Pliocene species of Austroparadoxostoma. Paradoxostoma resembles Austroparadoxostoma in the similarity of the copulatory organ, the normal pores and the fact that some species of Paradoxostoma have a caudal process. Paradoxostoma, however, has either an adont or lophodont hinge, the frontal scar, if discernable is ovoid 
and although certain Paradoxostoma have developed ridges the authors do not know of any in which such a prominent keel-like, ventrolateral, alar ridge occurs.

The Ostracoda of the St. Erth Beds are virtually unknown. Only 2 papers have been published which relate to the ostracod fauna, namely Whatley in Mitchell et al. (1973) and Maybury \& Whatley (1980). This paper represents the third in a series in which this diverse fauna is discussed.

\section{Austroparadoxostoma pliocenica sp. nov.}

(Pl. 1., figs. 1-7; Fig. 1).

Derivation of name. Latin, with reference to the occurrence of the species in the Pliocene deposits of Cornwall. Diagnosis. A medium sized paradoxostomatid with 2 well developed ridges; one traversing the entire length of the ventral margin, the other commencing at the ventral extremity of the caudal process; in the RV this ridge is obliquely disposed; but in the $\mathrm{LV}$ it parallels the keel-like, ventrolateral ridge. In both valves the dorsalmost ridge terminates near mid-length. Surface smooth. Normal pore canals simple, open, round, scattered and few in number. Inner lamella, hinge and muscle scars as for the genus. The inner lamella bears a weakly developed selvage and flange.

Holotype. RV, no. OS 12130. Paratypes: LV, OS 12131; RV, OS 12132 and LV, OS 12133.

Material. 9 adult valves, 7 juvenile valves and fragments of 4 additional juvenile valves.

Locality and horizon. St. Erth, near Hayle, Cornwall, England (Grid Ref. 556352). Upper Pliocene. Between 7.05 and $17.65 \mathrm{~m}$ fossiliferous marine clay. See Mitchell et al. (1973) for stratigraphy.

Description. Carapace almost assumes a parallelogram form in lateral view. Anterior margins oblique. Posterior margin in RV gently curved inward from a subdorsal, bluntly truncated caudal process to a well defined, ventrolateral ridge but in $\mathrm{LV}$ it is oblique with a rounded caudal process. In both valves the posterior and ventral margins meet obtusely, whereas the anteroventral angle is acute. Dorsal margin of RV convex anteriorly and slightly concave posteriorly, but gently arcuate in LV. Ventral margin of both valves convex to slightly sinuous with a prominent ventrolateral ridge produced dorsal to the ventral margin and projecting to the vertex of the valves which is at mid-length. The ventrolateral ridge does not obscure the ventral margin, but overhangs the anteroventral angle of both valves. Maximum length measured from the anterior extremity of the ventrolateral ridge to the posterodorsal extremity of the caudal process; maximum width at mid-length and coincident with the vertex of both valves. Each valve is approximately 3 times as long as it is high. In dorsal aspect, each valve forms a shallow arc within the greater arc of the ventrolateral ridge. The commissure is straight, but slightly concave in the anterior $1 / 3$. Weakly calcified, transparent to opaque.

Surface smooth with, in addition to the ventrolateral ridge, a second ridge commencing at the ventral extremity of the caudal process. In the $R V$ this ridge is obliquely disposed in the posterior $1 / 4$ and then becomes somewhat meandrine and less elevated. It does not traverse the anterior $1 / 4$ of the valve. In the $L V$, however, it is parallel to the ventrolateral ridge and tapers slightly posteriorly, terminating a little before mid-length. Normal pores simple, open and circular in cross section. They are few in number and irregularly situated.

Inner lamella very weakly calcified. There is a subtriangular vestibule anteriorly and a very narrow, crescentic vestibule posteriorly; otherwise the line of concresence is coincident with the inner margin. Anteriorly and posteriorly the inner lamella is relatively wide with its inner margin asymmetrically curved. Selvage and flange very poorly developed. There are 4 straight marginal pore canals anteriorly and one bifurcate and one straight canal posteriorly and 7 to 9 straight canals ventrally.

The hinge structure does not readily approximate to that of any previously described ostracod. In the RV there is no anterior terminal element, but the valve edge is thickened somewhat peripherally. The median element is composed of a broad, deep groove, which is locellate dorsally and closed ventrally by a broad ridge. The median groove is of constant width, except in its anterior $1 / 4$ where it tapers slightly distally. The ventral ridge is widest medianly and tapers anteriorly. A very deep and narrow groove borders the dorsal edge of the median element immediately below the dorsal edge of the valve. The posterior terminal element consists of a wide socket enclosed on all sides and a trilobate bar from

\section{Explanation of Plate 1}

Figs. 1-7. Austroparadoxostoma pliocenica sp. nov.: fig. 1, Paratype OS $12131 \mathrm{LV}$, ext. lat. $(\times 125)$; fig. 2, Holotype OS $12130 \mathrm{RV}$, ext. lat. $(\times 125)$; fig. 3, Paratype OS $12132 \mathrm{RV}$, detail of hinge $(\times 350)$; fig. 4, Paratype OS 12132 RV, detail of central muscle scars $(\times 600)$; fig. 5, Paratype OS 12133 LV. Internal view $(\times 125)$; fig. 6 , Paratype OS 12133 LV. Detail of hinge $(\times 350)$; fig. 7, Paratype OS 12132 RV. Internal view $(\times 125)$.

Fig. 8. Austroparadoxostoma sp.: RV, OS 12134, ext. lat. $(\times 150)$. 


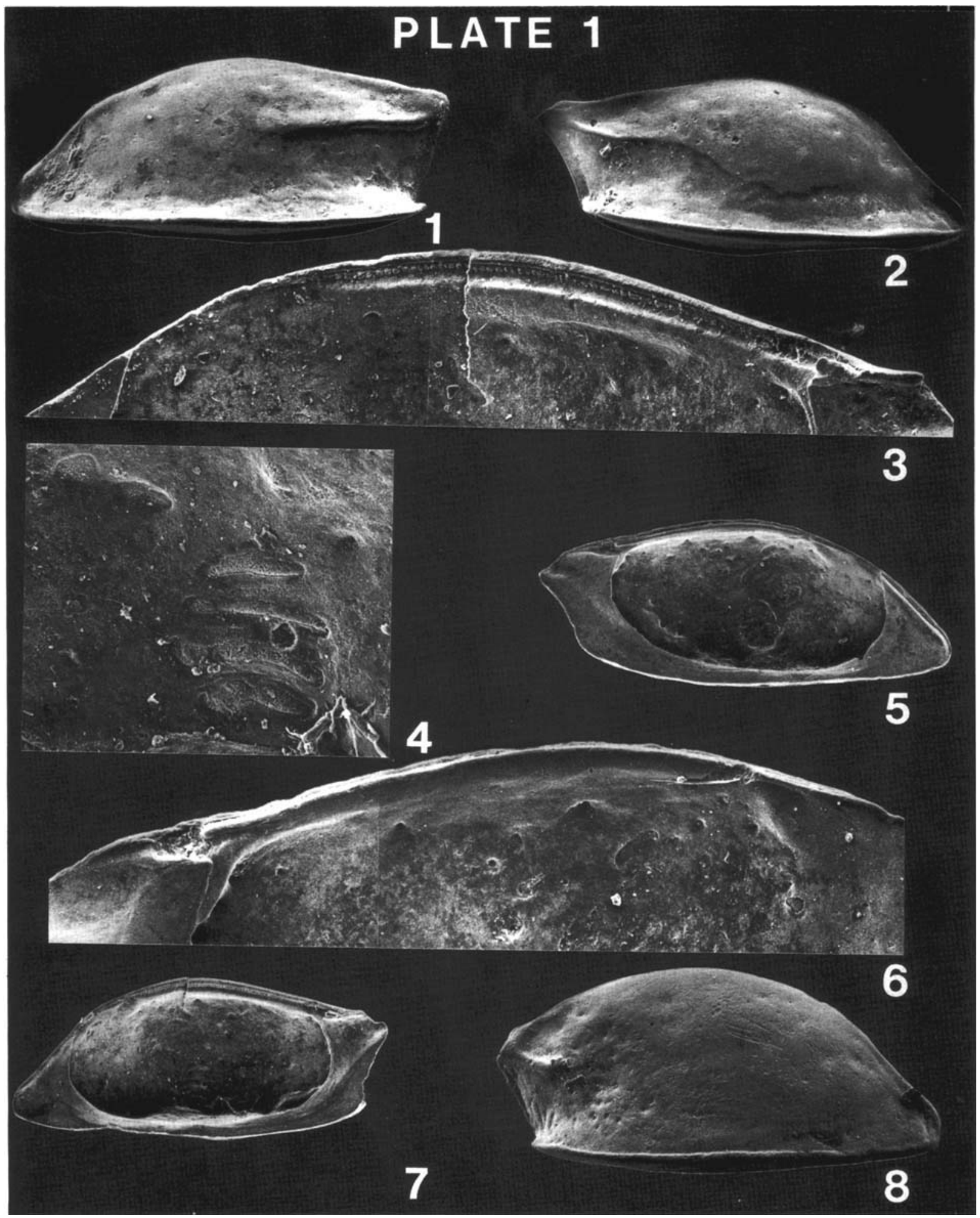



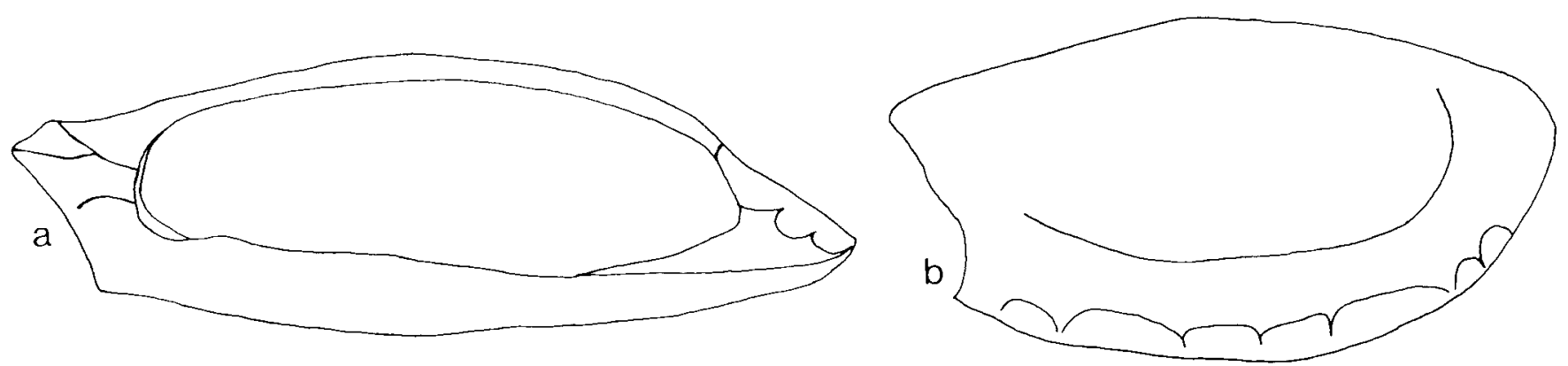

Fig. 1. Austroparadoxostoma pliocenica: a, RV, OS 12130.

External lateral view to show the anterior and posterior marginal pore canals $(\times 70)$; b, LV, OS 12131 . Internal lateral view with specimen slightly tilted to show the ventral marginal pore canals $(\times 70)$.

which an " $L "$-shaped elevation emerges mid-ventrally. The LV does not possess precise complementary structures to the RV in that the anterior terminal element consists of a shallow, rather indistinct socket, open dorsally. The median element itself is an ovoid socket, closed dorsally by the peripheral thickening of the dorsal margin and posteriorly and ventrally by an inverted " $L$ "shaped structure.

The adductor muscles are situated medianly with the dorsal-most scar just below mid-height. They comprise an oblique row of 4 contiguous or closely adjacent, elongate scars. Anterodorsal to these is a fulcral point situated very close to an irregularly shaped frontal scar.

Instar stages from Adult to ? A-3 have been recognised and it is notable that the juvenile valves are so weakly calcified that there is a tendency toward splitting along the juncture between the inner and outer lamellae; hence only the outer lamella is preserved.

$\begin{array}{ccc}\text { Dimensions (mm) } & \text { Length } & \text { Height } \\ \text { Holotype RV, OS } 12130 & 0.61 & 0.24 \\ \text { Paratype LV, OS } 12131 & 0.63 & 0.26 \\ \text { Paratype RV, OS } 12132 & 0.55 & 0.24 \\ \text { Paratype LV, OS } 12133 & 0.60 & 0.25\end{array}$

Remarks. Austroparadoxostoma pliocenica occurs rarely in the Upper Pliocene deposits of St. Erth. It has been recovered from both the brown calcareous and blue marine clay levels and from a mixed sample in which clay dominated. The occurrence of the new species in this mixed sample has rendered it impossible for the authors to give anything but a general description of the type level. It has not been found in deposits of equivalent age from East Anglia, N.W. France or the Vienna Basin studied by the authors.

$A$. pliocenica differs from the type species, $A$ ventromarginalis in being slightly less elongate, in the details of its muscle scar arrangement and possibly in its hinge structure. It is notable that both species occur as rare members of their respective faunas and that the genus itself should show such a widely disjunct geographical distribution over the time interval extending from the Upper Pliocene to the present day.

\section{Austroparadoxostoma sp.}

(Pl. 1, fig. 8)

Diagnosis. Austroparadoxostoma with smooth surface and few open normal pore canals; characterised by well developed ventrolateral ridge and short ridge extending obliquely anteroventrally from just above the apex of the bluntly truncated caudal process below which are a series of short radiating, subvertical grooves. Internal details as for genus.

Material. 1 adult RV.
Locality and horizon. As for A. pliocenica sp. nov.
Dimensions ( $\mathrm{mm}$ )
RV, OS 12134
Length
0.52
Height
0.25

Remarks. This species more closely resembles $A$. pliocenica sp. nov. than the type species. It differs from the $\mathrm{RV}$ of the former in its possession of fine, subvertical, radiating grooves and in being proportionally and absolutely higher and less elongate. In addition, the ridge extending from the caudal process is not as well developed as in A. pliocenica. The species is left in open nomenclature because of the extreme paucity of material.

\section{ACKNOWLEDGEMENTS}

The authors extend their thanks to Mr. T.N. Hitchens of Penzance, Cornwall and to Dr. J.E. Whittaker of the British Museum (Natural History) for providing the material for this study. Our thanks are also due to Mrs. S.E. Downing, Mr. H. Williams and Mr. D. Williams for their help with the photography; to Mr. C.J. Harlow for some useful suggestions and to Mr. N. McFarlaine for his help with translation. 


\section{REFERENCES}

Brady, G.S. 1870 . Notes on Entomostraca taken chiefly in the Northumberland and Durham district (1869). Trans. nat. Hist. Soc. Northumb., 3 (2), 361-373.

Coryell, H.N. \& Fields, S. 1937. A Gatun ostracode fauna from Cativa, Panama. Am. Mus. Novit., 956, 1-18.

Fischer, S. 1855. Beitrag zur kenntniss der Ostracoden. Abh. bayer. Akad. Wiss., 3 (7), 635-666.

Hartmann, G. 1979. Die Ostracoden der Ordnung Podocopida G.W. Müller, 1894 der warm-temperierten (antiborealen) West-und Südwestküste Australiens (zwischen Perth im Norden und Eucla im Süden). Mitt. hamb. zool. Mus. Inst., 76, 219-301.

Keij, A.J. 1957. Eocene and Oligocene Ostracoda of Belgium. Mém. Inst. r. Sci. nat. Belg., Brussels, 136, 1-210.

Kingma, J.T. 1948. Contributions to the knowledge of the young Caenozoic Ostracoda from the Malayan region. Kemink en Zoon N.V., Utrecht., 1-106.

Maybury, C. \& Whatley, R.C. 1980. The Ostracod genus Leptocythere from the Pliocene deposits of St. Erth and North-West France. Rev. Esp. Micropal., XII (3), 435-468.

Mitchell, G.F. et. al. 1973. The Late Pliocene marine formation at St. Erth, Cornwall. Phil. Trans. R. Soc., London, 266, $(874), 345-366$. 